\title{
47. Paradoxical Hyperglycemia in Carp Induced by Tolbutamide Treatment
}

\author{
By Mitsuo Nakamura, Yasuo InUi, and Motoyoshi Yokote \\ Department of Anatomy, Nagoya University School of Medicine and \\ Freshwater Fisheries Research Laboratory
}

(Comm. by Yô K. OKadA, M. J. A., March 13, 1972)

The hypoglycemic action of tolbutamide is well documented in various animals inclusive of rodents, carnivoras, birds, amphibians as well as humans. ${ }^{1)-7)}$ The most acceptable explanation for the major mechanism of this action of the drug is that it stimulates insulin secretion from the $B$ cells of the pancreas. ${ }^{8)}$

Against the results in higher vertebrates, we have found that the drug acts on the carp, Cyprings carpio by elevating blood glucose level. The present paper aims to report on the changes of the blood sugar level and accompanying ultrastructural changes of islet cells in tolbutamide treated carp.

A total of 76 carp of both sexes, aged about one year, were used. They were kept in aquaria supplied with flowing $20^{\circ} \mathrm{C}$ water.

After 24 hours' fast, these carp were offered for experiment. Thirty nine individuals were intramuscularly injected with different doses of sodium tolbutamide dissolved in physiological saline. Thirty individuals injected with physiological saline only, and seven without injection served as controls. At determined times after injection, four to ten animals were examined for blood sugar value. Non-treated controls also received analogous examination. For each animal, blood was taken only once from the dorsal aorta, under anaesthesia with MS 222. This is because repeated bleedings from the same individual easily cause hyperglycemia in the carp. ${ }^{9)}$ Blood glucose was determined by the Somogyi-Nelson procedure. ${ }^{10)}$ Immediately after bleeding, principal islets were excised, fixed in cold modified Dalton's fixative, ${ }^{11)}$ dehydrated and embedded in Epon 812. Thin sections of the islet tissues were stained with uranyl acetate and lead citrate and examined with a HU 11 A electron microscope.

First, the effect of a definite dose (500 mg. $/ \mathrm{kg}$. body weight) of tolbutamide upon the blood sugar level of the carp was investigated at 3, 6, 12 and 24 hours after drug administration. Sixteen animals given the sulfa drug were examined, together with equal numbers of saline injected and 7 non-treated carp as controls. Surprisingly enough, marked hyperglycemic reaction was observed: at 3 and 6 
Table I. Effect of $500 \mathrm{mg} . / \mathrm{kg}$. intramuscular tolbutamide on blood glucose in carp

\begin{tabular}{|c|c|c|c|c|c|}
\hline \multirow{3}{*}{ Treatment } & \multicolumn{5}{|c|}{ Blood glucose level (mg./dl.) } \\
\hline & \multicolumn{5}{|c|}{ Hours after tolbutamide } \\
\hline & (Non-treated) & 3 & 6 & 12 & 24 \\
\hline Tolbutamide injection & & $\begin{array}{c}89 \pm 8.2 \\
(4)\end{array}$ & $\underset{(4)}{93 \pm 9.3}$ & $50 \pm 10.0$ & $\begin{array}{c}43 \pm 4.7 \\
(4)\end{array}$ \\
\hline & $30 \pm 3.8(7)$ & & & & \\
\hline Saline iniection & & $\begin{array}{c}48 \pm 3.0 \\
(4)\end{array}$ & $\begin{array}{c}45 \pm 6.5 \\
(4)\end{array}$ & $\underset{(4)}{48 \pm 2.1}$ & $\underset{(4)}{43 \pm 4.6}$ \\
\hline
\end{tabular}

Figure in parenthesis denotes the number of animals.

Table II. Effect of various doses of intramuscular tolbutamide on blood glucose in carp

\begin{tabular}{cc}
\hline Treatment & $\begin{array}{c}\text { Blood glucose level (mg./dl.) } \\
\text { after } 6 \text { hours }\end{array}$ \\
\hline Tolbutamide injection & $65 \pm 3.9$ \\
$(250 \mathrm{mg} / \mathrm{kg})$. & $(4)$ \\
Tolbutamide injection & $88 \pm 6.8$ \\
(500 mg./kg.) & $(4)$ \\
Tolbutamide injection & $149 \pm 22.7$ \\
$(1000 \mathrm{mg} . / \mathrm{kg})$. & $(5)$ \\
Saline injection & $40 \pm 3.3$ \\
& $(4)$ \\
\hline
\end{tabular}

Figure in parenthesis denotes the number of animals.

hours, the blood sugar values of tolbutamide treated carp were significantly higher than those of saline injected and non-treated controls $(p<0.01) \quad$ (Table $I)$. The largest increase in the blood sugar value was noted at 6 hours.

Next, the relationship between the dose of tolbutamide and the intensity of the response was analysed, using 13 carp given three different doses $(250,500$ and $1000 \mathrm{mg}$. $/ \mathrm{kg}$. body weight) of the drug and, as controls, 4 saline injected individuals. Blood sugar was measured only at 6 hours after tolbutamide injection. As can be seen in Table II, each of the three doses caused significant increase $(p<0.01)$ in blood glucose level and the magnitude of the response appears to be in proportion to the dose.

Then, the effect of repeated administrations of tolbutamide on the blood sugar level of the carp was surveyed.

Two hundred $\mathrm{mg}$./kg. body weight of tolbutamide was injected into 10 individuals five times at the intervals of 3 hours. Ten individuals receiving five injections of physiological saline served as saline injected controls. One hour following the final injection, animals were analysed for blood sugar. 


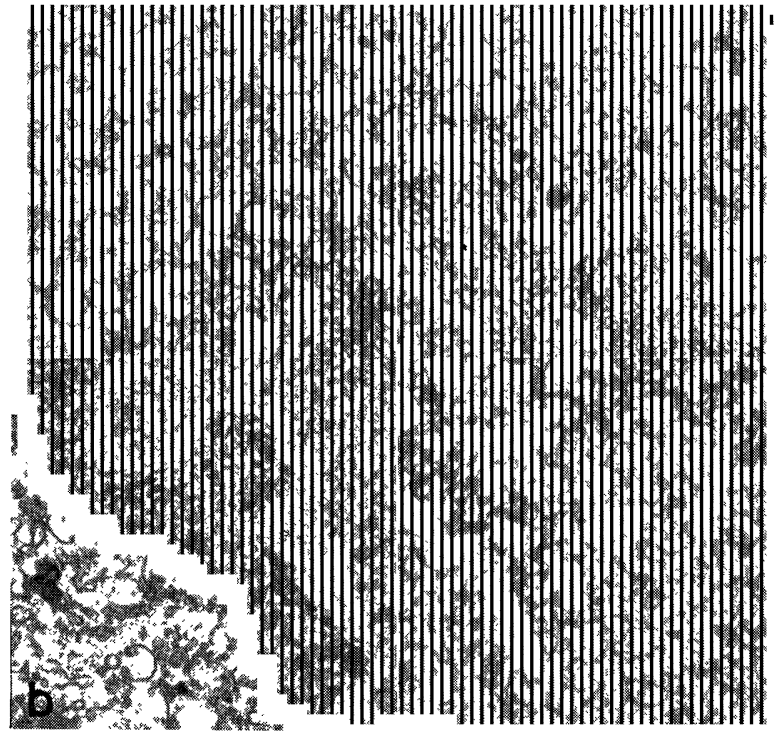

Fig. 1. Electron micrographs of insular $\mathbf{B}$ and clear cells in control and tolbutamide treated carp. a: A portion of a B cell of a control carp. $\times 12500$. $b: A$ portion of a clear cell of a control carp. $\times 12500$. $c:$ A portion of a B cell of a carp injected with $500 \mathrm{mg}$. $/ \mathrm{kg}$. body weight of tolbutamide. Many secretory granules undergo dissolution. $\times 12500$. $\mathrm{d}:$ A portion of a clear cell of a carp with repeated injections of tolbutamide. Larger cytoplasmic vacuoles are few. The elements of the endoplasmic reticulum and Golgi apparatus are proliferated. $\times 12500$.

It was found that the tolbutamide treated carp developed intense hyperglycemia. The blood sugar values after the treatment were as high as $199 \pm 31.5 \mathrm{mg} / \mathrm{dl}$, while those of saline injected controls were $89 \pm 9.7 \mathrm{mg}$./dl. It is worthy of note that saline injected controls also showed values remarkably higher than in non-treated carp examined in the first experiment. This is probably due to stresses added to the fish by frequent handlings. However, the blood sugar values exhibited by tolbutamide treated carp were even higher than those of saline injected controls, and the difference between both values was significant $(\mathrm{p}<0.01)$.

The present striking finding that tolbutamide induces hyperglycemia in the carp is meaningful, since it may extend knowledges on the pharmacologic action of the drug. However, we can not gain any insight into the mechanism underlying the paradoxal hyperglycemia in the carp. For the elucidation of this mechanism, further studies are needed.

Of the four types (A, B, clear and D) of islet cells identified in 
[Vol. 48,

the carp, ${ }^{12)}$ the $\mathrm{B}$ and clear cells exhibited ultrastructural changes following the administration of tolbutamide. The changes were especially prominent in carp given repeated injections of the drug. In the B cells, secretory granules tend to undergo dissolution (Fig. 1, $\mathrm{a}$ and $\mathrm{c}$ ), while the clear cells showed the diminution of larger cytoplasmic vacuoles and the proliferation of the elements of the endoplasmic reticulum and Golgi apparatus (Fig. 1, b and d). These morphological reactions can be taken to suggest increased insulin secretion from the B cells and enhanced activity of the clear cells. The fact that the clear cells react to tolbutamide as well as the B cells is of interest in the light of our idea ${ }^{12)}$ that the former cells are a variety of the latter. The details of the electron microscopic observations of islet cells will be published elsewhere.

\section{References}

1) W. Creuzfeld und H. Finter: Deutsche Med. Wochnschr., 81, 892 (1956).

2) G. Mohnike und H. Bibergeil: Deutsche Med. Wochnschr., 81, 900 (1956).

3) B. A. Houssay, J. C. Penhos, N. Teodosio, J. Bowkett, and J. Apelbaum: Ann. N. Y. Acad. Sci., 71, 12 (1957).

4) I. A. Mirsky and S. Gitelson: Endocrinol., 63, 345 (1958).

5) I. A. Mirsky, D. Diengott, and H. Dolger: Metabolism, 5, 875 (1956).

6) R. S. Yalow, H. Black, M. Villazon, and S. A. Berson: Diabetes, 9, 356 (1960).

7) D. Maingay, H. A. De Ruyter, J. L. Tumber, R. J. M. Croughs, W. Shopman, and R. M. Lequin: Lancet, 1, 361 (1967).

8) E. F. Pfeiffer, M. Pfeiffer, H. Dischuneit, and C. Ahn: Ann. N. Y. Acan. Sci., 82, 479 (1959).

9) M. Yokote: Bull. Jap. Soc. Sci. Fish., 36, 1214 (1970).

10) N. Nelson: J. Biol. Chem., 153, 375 (1944).

11) K. Yamada and M. Nakamura: Technics of Electron Microscopy (Ed. Kanto Branch of Japanese Society of Electron Microscopy) Seibundo-Shinkosha, p. 302. Tokyo (1970).

12) M. Nakamura and M. Yokote: Z. Anat. Entwickl.-Gesch., 134, 61 (1971). 